\title{
Contemporary societal division: resonance, alienation, and (politics of) fear
}

\author{
Bojan Zalec
}

DOI: 10.18355/XL.2022.15.01.11

\begin{abstract}
The current situation is marked by a negative attitude of people towards politics and division between them. The author shows how we can understand the nature and origin of such a condition with the help of Rosa's resonance theory and his theory of action. Rosa interprets the modern situation as alienation between people and politics and as a reaction of people to it. On this basis, the author explains the functioning of the politics of fear. He shows that the foundation of the fight against the politics of fear is to improve our relationships in terms of resonance. The author concludes that Rosa's theory is very useful for understanding the central social and political problem of the modern world, the division between people and politics, which is also a major problem for democracy. Therefore, discussing this theory, elaborating it, applying it and developing it is very relevant and beneficial.
\end{abstract}

Key words: Hartmut Rosa, resonance, alienation, action theory, division between people and politics, politics of fear

\section{Introduction}

In this article, I deal with Hartmut Rosa's resonance theory and its explanatory potential. I demonstrate its usefulness for understanding and for solving one of the central problems of the modern world, the division and alienation between people and politics. The term 'politics', as I use it here, refers to politicians, political institutions, governments, authorities etc. This problem is political in the broad sense of the term, but it has deeper origins which are of existential nature. The aim of this article is to enlighten these origins. The manifestations of this problem are contemporary protests of people against politics and populist anti-democratic movements that threaten liberal democracy. They are worldwide phenomenon. In this context, the politics of fear plays an important role. I explain it using the theory of the contemporary German sociologist Hartmut Rosa, which has aroused great interest in recent years (Peters, Schulz, 2017; Kladen, Schussler, 2017; Wils, 2019; Rosa, Henning, 2019; Laube, 2018; Rosenstock, 2018; Klun, 2020; Hubner, 2021; Zalec, 2021a; 2021b). I explain the origin, character, and the function(ing) of the mentioned phenomena in terms of alienation, lack of resonance, and the fear of losing it.

At the beginning, I briefly present the general features and components of Rosa's resonance theory, only to the extent necessary for the purposes of the paper. In this respect the notions of resonance and alienation, which is the "other" of resonance (Rosa, 2019c: 178), are very important. Resonance and alienation are central categories of Rosa's theory of our relationship to the world. Another pair of important concepts are desire and fear. They are the basis of his theory of action, which plays a key role in my explanations.

The structure of the article is as follows. In the first part I present the general features and components of Rosa' theory. In the major part I present his understanding of contemporary societal division and crisis of democracy. I explain the nature of the division between politics and people, which makes it possible to understand the conflicts and protests that characterize the modern situation worldwide. 


\section{General essential features of (theory of) resonance}

Let us now briefly explain the concept of resonance as it is explained in Rosa's resonance theory (Rosa, 2016; 2019a; 2019b; 2019c; 2019d; Zalec, 2021a, 143ff; 2021b). Rosa understands resonance as a relationship with the world in various dimensions. It is a reciprocal, two-sided relationship, which means that resonance requires both a passive, pathic, and an active, acting participation of both sides or participants in resonance. It has four essential characteristics (Rosa, 2019b: 196): 1. affection (Ger. Affizierung); 2. self-efficacy (Ger. Selbstwirksamkeit); 3. transformation (Ger. Transformation); 4. unavailability or inaccessibility (Ger. Unverfügbarkeit) (Rosa, 2019d). In order for a resonance relationship to occur, both sides in a relationship - not just one of them - must have all four characteristics. From what has been said it is clear that responsiveness and inwardness are integral parts of resonance.

The "other" of resonance is alienation (Rosa, 2019c: 178), which is a "relationship" of indifference or even hostility. To the subject, object or world appears as dumb, deaf, unresponsive, as bare available material, and so on. It is a dead relationship, a "relation of relationlessness." (Jaeggi, 2014: 3-50; Rosa, 2019c: 27, 178, 184)

We are in resonance with someone if something in this relationship touches them and me, if I affect them and they affect me, and if this relationship more or less changes us both. The resonance relation cannot be controlled and arbitrarily produced (Rosa, 2018: 2019d), we do not have it at our disposal. The engineering of resonance is not possible. An example of the resonant relationship is love, and resonance is an essential part also for faith. I repeat, it is very important from the ethical and moral point of view that resonance is a two-way relationship: one cannot resonate on their own, the other side must also be active. Just like one cannot clap with only one hand. Resonance is not listening to one's own echo or monologue with oneself, but it is a contact and relationship with objective reality, with the real world. Resonance implies a real relationship with the world, a realistic stance. In resonance we do not listen to ourselves and to our projection of the world. Resonance is like dialogue, dialogue with the world, which goes in both directions, when the other or the world actually speaks with its voice and that voice reaches us. In fact, dialogue is an example or a form of resonance (Rosa, 2019a: 22; Zalec, 2021a: 145). The key conditions of dialogue and the constituents of true dialogue are equality, empathy, and freedom. (Yankelovich, 2001: 41-44) Dialogue must be in principle free of any obligations or objectives, e.g. reaching a consensus. This is especially evident in very difficult and complicated situations, when the only way to start solving the problem is to get rid of all the goals and honestly say, "Let's leave everything else for once, and just try to understand each other's situation as much as humanly possible. Nothing else, no other obligations." I can also mention the absence of taboos and the disclosure of assumptions and central positions of the participants (ibid.: 44).

Suppressing resonance and depriving others of resonance is always paid for with the quality of our own lives. The ideal of resonance therefore, as such, includes motivation for moral behaviour, because in order for me to be in resonance, others must be in resonance too. (Rosa, 2019b: 207) This motivational potential of resonance for the one who is aware of how it works is very important, because even bright ideals for which we cannot answer what a person gains or loses if they don't respect them, they remain just a dead letter. Past and present experiences teach us about this. In addition, resonance can serve us as a compass in otherwise unsolvable moral dilemmas, and as an ideal that grounds our morality. (Rosa, 2019b: 206-207)

XLinguae, Volume 15 Issue 1, January 2022, ISSN 1337-8384, eISSN 2453-711X 


\section{The origins of the contemporary crisis of democracy in the light of Rosa's theory of resonance}

In this section, I present Rosa's understanding of the contemporary political situation in "our" late modernity. We can proceed from the fact that everywhere in the world we can observe a great division between people and politics, i.e. politicians, authorities, government, political institutions, etc. We can say that the modern world in this respect is characterized by great alienation between people and politics. The typical attitudes of people regarding politics in such a situation are either cynical ridicule or anger and loud shouting against politics, which is getting louder and louder at protests all over the world. The anger of people over such a division and the current political situation can be better and more deeply understood theoretically if we apply Rosa's theory of resonance and the theory of action based on it.

Our elementary relationships to the world according to Rosa are desire and fear. The things or the world appears to us as attractive (desire) or as repulsive (fear). Desire and fear are subjective aspects. Their objective correlates - aspects of the world - are attraction and repulsion. (Rosa, 2019c: 111) According to Rosa's theory of action the main drives of human beings are their searching for the oases of resonance and avoidance of the deserts of alienation. (Ibid., 114: 117)

If we apply this theory to the described situation of division and alienation between people and politics, we can say that those who shout want primarily to be heard, they are essentially protesting and shouting against the state of alienation. People feel alienated not only in terms of economic participation and decisions but also in terms of politics. These reactions are manifestations of people's feeling that there is no resonance between people and government, between people and politicians. In fact, they are not shouting against any particular political subject, but against the situation we are in, against the petrified structures, against the unresponsiveness of the sociopolitical world. If their anger is directed against concrete politicians, parties, government, etc. it is because they are perceived as representatives of such a state. But in fact today it is no longer a real question the question of political orientation, for example left or right. This was typical of the mid-20th century. Today people are (increasingly) aware that the problem is not in this or that particular political agent or orientation. Experience and observation can teach them this, as they see that all political subjects act very similarly when they find themselves in this or that situation, regardless of their political colours. For example, when they find themselves in the government position, they act very similarly. Such acting is justified by politicians on the pretext that there are "no alternatives" (this slogan was made famous by Margaret Thatcher when she advocated her free-market policies), as certain structural adjustments or reforms are simply necessary. (Rosa, 2019c: 224) For example, we are all against unemployment, but if necessary, the measures that cause it are taken by both left-wing and right-wing governments, saying that otherwise the economy will not survive. (Ladwig, 2006: 111; Rosa, 2019c: 224) The same goes for the ecological problems, education, health care, social services, etc.

What are the origins of the mentioned alienation between people and politics? As one important factor, Rosa mentions general social acceleration. There is no time for making decisions in a democratic way. This brings the feeling of doubtfulness about the perspective of the idea of political management of social developments because the lack of time causes that politicians wander confusedly through changes, politics is behind the social and other changes, and if it has already taken decisions, they are anachronistic because the pace of political decision-making cannot keep pace with changes. The result is that politics is no longer an agent dictating social developments and their pace. (Rosa, 2019c: 222-223)

The main explanation that Rosa gives of the division between people and politics is in terms of double loss of resonance. (Rosa, 2019c: 224) Rosa finds the double loss of resonance as the best explanation of the current state of division. The first loss is the 
deficit of self-efficacy. Politicians don't listen to us anyway. What we feel, want, and need means nothing to them and to their policies. This is what many people feel, and this is a paradigmatic expression of one side of the loss of resonance. This clearly indicates a certain deficit on the self-efficacy side of the resonance wire. The second loss is the deficit of one's own affection. Political programs can afford not to touch citizens. They can afford this to the extent that they are presented and understood, interpreted as necessary structural adjustments or policies constrained by reality. The discourse of "no alternative" is used, as already mentioned. Thus, citizens feel that their demands are not heard. They feel as powerless individuals alienated not only from economic but also from political participation and decisions. They find the socio-political world unresponsive. Therefore, people's demands for resonance are not primarily focused on "out of touch" politicians (or, if they are, only on them as deputies, representatives, vicariously), but on petrified relations of the social world, which can no longer be adaptively transformed. The empowered political subject, as one of the fundamental promises of modernity, is being increasingly replaced by a powerless individual who feels alienated not only economically, but also politically. The shouting protesters are primarily and foremost interested in being perceived and recognized as political subjects with their own voice, and not some political party (left or right etc.) option. The specific political goals they are fighting for or declaring as their own are often contingent. What primarily unites these protesters is by no means a political program. (Ibid.: 223) The front line of civil society does not run between the left and the right, between religiosity and secularism (Nguyen, Valcova et al., 2020), between environmentalists and technicians (Nguyen, Truong et al., 2020; Ambrosy et al., 2020), but between citizens and politics. (Ibid.: 223-224)

Such a situation is favourable for generating phenomena that Rosa calls empty resonance waves. The phenomena are not genuine resonance, but confinement in the chamber of one's own echo. What Rosa has here in mind includes the mass protests against politics that are happening all over the world. As I have already explained, these protests are a sign and expression of alienation between people and politics. However, according to Rosa, they are not resonance between two sides, but a "monologue" or listening to oneself. Rosa believes that these protests cannot bring about necessary social transformations. (Ibid.: 224-225) There are several reasons for this. We have already mentioned one thing: these protests do not create resonance between societal subjects. Rosa notes that the more intense the protests, the less resonant they are. Second, they are not democratic. The square is not identical to people. On the protests many voices are not heard. So, we can say that the mentioned protests do not bring an improvement of resonance in the society. For the necessary changes, however, this is exactly what is needed, the improvement of relationships in terms of resonance. These protests, these waves of empty resonance, are relatively easy to generate in today's digitally interconnected world. But they are, in Rosa's view, merely an expression of anger and rage against the current situation. In this way we can make our voice heard, but we will not come to any genuine political collective action, no genuine experience of political self-efficacy and thus to no true collective transformation. At most, we can stop a political project or overthrow an individual or a political regime.

Rosa believes that because of the alienation between people and politics, saying that we have entered a post-democratic age might be correct. In addition to the already mentioned attitudes towards politics, cynical ridicule or furious shouting, it is characteristic of that era that voting in elections loses its meaning, both objectively and subjectively. Objectively in the sense of a declining voter turnout, and subjectively in the sense that both voters and non-voters increasingly feel that it does not matter who they vote for. Thus, instead of voting, cynical ridicule and loud shouting (at protests) are increasingly becoming the predominant manifestations of

XLinguae, Volume 15 Issue 1, January 2022, ISSN 1337-8384, eISSN 2453-711X 
the political voice. Rosa stresses that cynical laughter and shouting against are not only undemocratic, or at least non-democratic, forms of expression, but are also indicators of a repulsive attitude and mode of relation showing that the resonance wire between citizens is mute. (Rosa, 2019c: 222) He notes that everywhere in the world, regardless of the democratic, semi-democratic, or autocratic nature of a given regime, we can observe a similar division between the people and the government. Everywhere we find people shouting against an "alienated" government, which often reacts to them with repulsion and even violence. (Ibid.: 223)

However, Rosa also draws attention to the phenomena that herald a new democratic era. In this sense, he mentions "innovative democratic institutions" that are truly capable of creating spaces of political resonance. These are forms of cooperation and collaboration that are still in development. In this regard, Rosa mentions sharing economy, transition towns, new creative communities and cooperatives, cases where people reappropriate institutions of energy supply and infrastructure, which as a community they buy back (from the private market). (Ibid.: 225)

\section{Politics of fear}

A very important feature of our time and situation is politics of fear. Let me now briefly explain - by using Rosa's theory - how it functions. As we saw, the man of late modernity is afraid because they are afraid of losing resonance. But they don't know exactly what they are afraid of. Then someone comes and shows them a certain "object" and says: "This is what you are afraid of," and make a "promise": "If we get rid of these objects, you will no longer be afraid, your fear and anxiety will disappear." And many people buy this. Such objects can be called scapegoats of fear. The politics of fear exploits such scapegoats. This is very practical and effective for populist politicians, as there are many people who like simple and comprehensive explanations.

The scapegoats of the politics of fear can be very different, there are no principled restrictions for them. They are used by all parties in a political conflict. They use different entities in the same environment as scapegoats. These can be migrants, LGBT, the current government, religious communities or churches, ethnic groups, political parties, movements, groups, organizations, individual politicians, etc. In his works, René Girard points to some qualities of individuals or groups that are positive factors of their becoming scapegoats (Girard, 1986: 12-23; Palaver, 2013: 135-150), but there are no principled criteria for becoming a scapegoat or a target of politics of fear. Things depend very much on particular situations and concrete context. In any case, the situation of a social or cultural crisis is very favourable and stimulating for scapegoating, as Girard has already noted (Girard, 1986: 12ff), and the politics of fear. The proliferation of fear politics is very harmful and dangerous. We can only limit it if we reduce people's fear (of losing resonance). In this regard, Rosas's theory can help freeing one from fear. Rosa's project of freeing man frees them internally and externally. Internally by helping them realize what their real fears are, what they really fear, and externally by trying to weed out the social factors that are the negative factors of stable resonance axes and increase and reinforce their positive factors. It is important to realize that Rosa constantly emphasizes that resonance is precarious in nature, that resonances are fleshes in the world of alienation. (Rosa, 2019c: 185; Laube, 2018: 366) Therefore, Rosa does not think that permanent resonance is possible in this world. What can be permanent, however, is the disposition for resonance and the factors and conditions that allow this disposition in humans to develop and strengthen. These dispositions are necessary for stable axes of resonance to be available to man. These two can be influenced by the formation of society and therefore resonance theory can be social theory. (Laube, 2018: 367-368; Susen, 2020) Resonance itself, however, is not available and cannot be controlled. Resonance engineering is not possible. (Rosa, 2019d) 


\section{The political potential of resonance and the danger of political abuse of human longing for it}

According to Rosa, the demand for resonance can be understood as the driving force behind communitarian and perhaps even modern convivalist movements. The same can be said for the 1968 protests and the environmental movement, which became particularly palpable in the radical atmosphere of the late 1960s and early 1970s. Revolt of that time was first and foremost an aesthetic and musical revolution that drew its strength largely from the "musicalization of politics and the politicization of music". The transformative political power of rock music was again manifested in political and civic movements in the coming decades. (Rosa, 2019c: 222) Even today, authoritarian and totalitarian rulers have good reason to fear and persecute this music because pro-democratic forces want to use it as a weapon. Nevertheless, Rosa notes that, at least in the West, faith in pop and rock music as a political transformational force to revolutionize our collective attitude toward the world is largely dead. Pop culture has become predominantly non-political. (Ibid.: 221-222)

Rosa's resonant concept of politics and democracy moves between the associative $(\mathrm{H}$. Arendt) and the dissociative (C. Schmitt) concept:

"With its emphasis on contradiction, viscerality, and diversity of voices, resonance theory tends toward the dissociative view, yet with its notion of sounding together, of moving responsive relationships, it also embraces the associative, republican vision of common action and the productive adaptive transformation of public spheres and institutions" (ibid.: 219).

Rosa advocates a "politics of resonance" (ibid.: 458), but also warns of the danger that misusing of the human longing for political resonance represents to recognition and protection of difference and diversity. He finds that the line between a genuine response that not only allows but requires opposition, and the identitarian concept of "resonance" as echo is very thin. This danger is illustrated by the history of fascism and especially German Nazism. (Ibid.: 219ff) According to Rosa, there is no doubt that one of the reasons for the political success of fascism, and especially Nazism, is that they knew how to exploit the longing for resonance, which strongly permeates man and is deeply rooted in him. (Landweer, 2019: 61ff) They have created in people a sense that politics is responding again to ordinary citizens. These movements literally caused the world to vibrate and resonate, resound. With their parades, songs, rituals, steps, etc. the Nazis staged a huge spectacle of resonance that touched people directly and "viscerally". (Rosa, 2019c: 219) In the sphere of identitarian resonance, the "unity of the people" was literally staged. (Ibid.: 220)

\section{The importance of resonance politics}

The discussion in this paper shows how important resonance is from the political point of view and that without resonance theory we cannot understand the modern division between people and politics. (Taylor, 2019: 75ff) We can see what problems the absence of resonance causes. People long for resonant relationships in politics. Otherwise, they are dissatisfied and this dissatisfaction manifests itself either as a cynical and ridiculous attitude towards politics or as a loud shout against politics. Both threaten democracy and a certain degree of resonance is essential for the functioning of democracy. Therefore, cultivating the policy of resonance is necessary if we want to live in a democracy of "happy" citizens, even if this cultivation is not without danger, as people's longing for political resonance can be abused, as the examples of fascism and Nazism show. However, we need to be aware that this need exists in people and they try to satisfy it. If it cannot be satisfied by democratic political agents, non-democratic political actors will take advantage of it. This is exactly what is happening all over the world today in the form of various populist

XLinguae, Volume 15 Issue 1, January 2022, ISSN 1337-8384, eISSN 2453-711X 
anti-democratic movements. Therefore, the solution to democracy is not in the "fear" of resonance, but in cultivating genuine resonance in the political sphere. Therefore, this effort can serve as a benchmark to distinguish true democrats from non-democrats or fake democrats.

Because resonance is necessary for democracy and real participation in politics, it is also very important for good life of people, for their happiness (Zalec, Pavlikova, 2019a; 2019b). Modern empirical research confirms the findings of Hannah Arendt on the importance of political participation for human satisfaction. They provide evidence that there is a direct correlation between people's satisfaction with their lives and their ability to participate in democratic politics. (Rosa, 2019c: 219) It is not so much the individual's satisfaction with the results of participation that is important, but rather that they are involved in the political process. Rosa quotes Swiss economist Bruno S. Frey, who wrote that the people of countries with widespread democracies are fundamentally more satisfied with their lives than those who live under the same conditions, but in undemocratic societies. (Ibid.) Democracy and political participation therefore have a significant impact on people's quality of life, both of which presuppose resonance.

\section{Conclusion}

Rousseau distinguished between the collective and the general will. The collective will is the opportune matching of individual wills that are matched or connected for their own interests. The common will, however, focuses on the common good. Neglecting the common will and relying solely on the achievement of the collective will, can cost societies dearly in the form of their disintegration, which manifests itself in ever greater and sharper conflicts and polarizations. Besides growing polarization of societies, also the environmental problems, mental health problems (depression, burnout), consumerism, and more, show that we need an alternative to the current situation. Rosa argues that the root of all these problems lies in the lack of proper relationships. He offers an integral resonance model as an alternative. Resonant relationships are the central and fundamental common good that we must achieve in order to overcome our most burning problems. I find his proposal very promising. It really touches the nerve and roots of the mentioned issues. In the article I explained on the example of crisis of democracy - why I think so. Despite the differences among us, most of us feel and think, just on intuitive and everyday empirical basis, or for more theoretically elaborated reasons, that something is wrong. I think Rosa's theory describes and interprets very well what is wrong, what really bothers us, enlightens the main origins of the crisis, and outlines what is basically the right way of coping with the problems. This is I think, besides the enormous interest it has aroused between scientists, and in broader circles, a very good reason to discuss about his proposal/theory, to elaborate, extend and apply it.

\section{Acknowledgment}

The Research Programme Ethical-religious Grounds and Perspectives of the Society and the Religious Studies in Context of Education and Violence (P6-0269) and the basic research projects Holistic Approach to Business and Human Rights: A Normative Reform of Slovenian and International Legal Order (J5-1790) and Slovenian Intellectual History in the Light of Contemporary Theories of Religion: From Separation of Spirits and Culture War to Communist Revolution (J6-3140) are financed by the Slovenian Research Agency. This article was published with the support of the mentioned programme and projects. I thank the Agency for the support.

\section{Bibliographic references}

Ambrosy, M., Krempasky, J., Kalugina, O. A., Sizova, Z. A., Krokhina, J. A., \& Valco, M. (2020). Christianity and Information: Contribution of Stephen Hawking to 
Physics, Philosophical Ethics, and Theology. Bogoslovni vestnik 80(4), 901-914. ISSN 0006-5722.

Girard, R. (1986). The Scapegoat. Baltimore, Maryland: The John Hopkins University Press. ISBN 0-8018-3315-9.

Hubner, J. (2021). Reich-Gottes-Hoffnung als Auferstehung-Resonanz. Hartmut Rosas Resonanzkonzept ins Gespräch gebracht: ein theologisches Experiment. Evangelische Theologie 81(3), 223-236. ISSN 0014-3502.

Jaeggi, R. (2014). Alienation. New York: Columbia University Press. ISBN 978-0231-15198-6.

Kladen, T., \& Schußler, M. (eds.). (2017). Zu schnell für Gott? Theologische Kontroversen zu Beschleunigung und Resonanz. Freiburg et al.: Herder. ISBN 978-3451-02286-9.

Klun, B. (2020). Rezilienca in resonanca: v iskanju nove drže do sveta. Bogoslovni vestnik 80(2), 281-292. ISSN 0006-5722.

Ladwig, B. (2006). Moderne Sittlichkeit: Grundzüge einer 'hegelianischen' Gesellschaftstheorie des Politischen. In: Hubertus Buchstein and Rainer SchmalzBruns (eds.), Politik der Integration: Symbole, Repräsentation, Institution. BadenBaden: Nomos, 111-135. ISBN 978-3-8329-1758-6.

Landweer, H. (2019). „Gute“ und „schlechte“ Resonanzen? Ein Vorschlag zur Erweiterung von Hartmut Rosas Resonanztheorie. In: J.-P. Wils (ed.), Resonanz. Im interdisziplinären Gespräch mit Hartmut Rosa. Baden-Baden: Nomos, 57-69. ISBN 978-3-8487-4645-3.

Laube, M. (2018). 'Eine bessere Welt ist möglich.' Theologische Überlegungen zur Resonanztheorie Hartmut Rosas. Pastoraltheologie 107, 356-370. ISSN 0720-6259.

Nguyen, Q. H., Valcova, K., Zakirova, V. G., Larionova, A. A., \& Lapidus, N. I. (2020). Western science, religion and Vietnamese traditional culture: harmony or antagonism? XLinguae 13(3), 94-113. ISSN 1337-8384.

Nguyen, T. T., Truong, Q. T. T., Valco, M., Khvatova, M. K., \& Tyazhelnikov, A. A. (2020). Christian Theological Views on Industrial Revolutions and Related Ethical Challenges: A Western (and a Global) Perspective. Bogoslovni vestnik 80(1), 177 190. ISSN 0006-5722.

Palaver, W. (2013). René Girard's Mimetic Theory. East Lansing: Michigan: Michigan University Press. ISBN 978-1-61186-077-1.

Peters, C.H., \& Schulz, P. (eds.). (2017). Resonazen und Dissonanzen. Hartmut Rosas kritische Theorie in der Diskussion. 2017. Bielefeld: transcript Verlag. ISBN 978-38376-3565-2.

Rosa, H. 2016. Resonanz. Eine Soziologie der Weltbeziehung. Berlin: Suhrkamp. ISBN 978-3-518-29872-5.

Rosa, H. 2018. Unverfügbarkeit. Wien: Residenz Verlag. ISBN 9783701734467.

Rosa, H. (2019a). Resonanz als Schlüsselbegriff der Sozialtheorie. In: J.-P. Wils (ed.), Resonanz. Im interdisziplinären Gespräch mit Hartmut Rosa. Wils. Baden-Baden: Nomos, 11-30. ISBN 978-3-8487-4645-3.

Rosa, H. (2019b). Zur Kritik und Weiterentwicklung des Resonanzkonzepts. In: J.-P. Wils (ed.), Resonanz. Im interdisziplinären Gespräch mit Hartmut Rosa. BadenBaden: Nomos, 191-212. ISBN 978-3-8487-4645-3.

Rosa, H. (2019c). Resonance: A Sociology of our Relationship to the World. Cambridge, UK and Medford, MA, USA: Polity Press. ISBN 978-1-5095-1989-7.

Rosa, H. (2019d). The Uncontrollability of the World. Cambridge, UK, Medford, MA, USA: Polity Press. ISBN 13: 978-1-5095-4315-1.

Rosa, H., \& Henning, C. (eds.). 2019. The Good Life Beyond Growth: New Perspectives, eds. Hartmut Rosa and Christoph Henning. New York et al. Routledge. ISBN 978-0-367-34044-5.

XLinguae, Volume 15 Issue 1, January 2022, ISSN 1337-8384, eISSN 2453-711X 
Rosenstock, R. (2018). 'Etwas, was nicht ist und doch nicht nur nicht ist.' Konturen einer resonanzsensiblen Theologie im Gespräch mit Hartmut Rosa. Pastoraltheologie 107, 401-407. ISSN 0720-6259.

Susen, S. (2020). The Resonance of Resonance: Critical Theory as a Sociology of World-Relations? International Journal of Politics, Culture, and Society 33, 309-344. ISSN 1573-3416. Available online: https://doi.org/10.1007/s10767-019-9313-6

Taylor, C. (2019). The Ethical Implications of Resonance Theory. In: J.-P. Wils (ed.), Resonanz. Im interdisziplinären Gespräch mit Hartmut Rosa. Baden-Baden: Nomos, 71-85. ISBN 978-3-8487-4645-3.

Wils, J.-P. (ed.). (2019). Resonanz. Im interdisziplinären Gespräch mit Hartmut Rosa. Baden-Baden: Nomos. ISBN 978-3-8487-4645-3.

Yankelovich, D. (2001). The Magic of Dialogue: Transforming Conflict into Cooperation. New York, London, Toronto, and Sydney: Simon \& Schuster.

Zalec, B., \& Pavlikova, M. (2019a). Religious tolerance and intolerance. European Journal of Science and Theology 15(5), 39-48. ISSN 1841-0464.

Zalec, B., \& Pavlikova, M. (2019b). Civic virtues and functions of religion in public life. European Journal of Science and Theology 15(6), 75-84. ISSN 1841-0464.

Zalec, B. (2021a). Resonance as integral part of human resilience. XLinguae 14(3), 139-149. ISSN 1337-8384.

Zalec, B. (2021b). Rosa's Theory of Resonance: Its Importance for (the Science of) Religion and Hope. Religions 12, 797. Available at: https://doi.org/10.3390/rel12100797. ISSN 2077-1444.

Words: 5083

Characters: 33352 (18,53 standard pages)

Professor Bojan Žalec, PhD.

Faculty of Theology

University of Ljubljana

Poljanska c. 4

1000 Ljubljana

Slovenia

bojan.zalec@teof.uni-lj.si 